Case Report

\title{
A Case of Myeloproliferative Neoplasm with BCR-FGFR1 Rearrangement: Favorable Outcome after Haploidentical Allogeneic Transplantation
}

\author{
Paola Villafuerte-Gutiérrez $\mathbb{D}^{\mathbb{D}},{ }^{1}$ Montserrat López Rubio, ${ }^{1}$ Pilar Herrera, ${ }^{2}$ and Eva Arranz ${ }^{3}$ \\ ${ }^{1}$ Department of Hematology, Hospital Universitario Príncipe de Asturias, Alcalá de Henares, Madrid, Spain \\ ${ }^{2}$ Department of Hematology, Hospital Universitario Ramón y Cajal, Madrid, Spain \\ ${ }^{3}$ Cytogenetic Unit, Hospital Universitario de La Princesa, Madrid, Spain
}

Correspondence should be addressed to Paola Villafuerte-Gutiérrez; pvillafuerteg@gmail.com

Received 10 August 2018; Accepted 5 November 2018; Published 6 December 2018

Academic Editor: Stephen Langabeer

Copyright (C) 2018 Paola Villafuerte-Gutiérrez et al. This is an open access article distributed under the Creative Commons Attribution License, which permits unrestricted use, distribution, and reproduction in any medium, provided the original work is properly cited.

\begin{abstract}
Hematopoietic myeloproliferative neoplasms with FGFR1 rearrangement result in the 8p11 myeloproliferative syndrome that in the current Word Health Organization classification is designated as "myeloid and lymphoid neoplasm with FGFR1 abnormalities." We report the case of a 66-year-old man who had clinical features that resembled chronic myeloid leukaemia (CML), but bone marrow cytogenetic and fluorescent in situ hybridization (FISH) studies showed $t(8 ; 22)(\mathrm{p} 11 ; \mathrm{q} 11)$ and BCR-FGFR1 fusion gene. He was initially managed with hydroxyurea, and given the aggressive nature of this disease, four months later, the patient underwent an allogeneic hematopoietic stem-cell transplantation (HSCT) from an HLA-haploidentical relative. Currently, HSCT may be the only therapeutic option for long-term survival at least until more efficacious tyrosine kinase inhibitors (TKIs) become available.
\end{abstract}

\section{Introduction}

Hematopoietic myeloproliferative neoplasms (MPN) with rearrangements of fibroblast growth factor receptor 1 (FGFR1) gene (located on chromosome 8p11) are uncommon and extremely aggressive entities. Translocations associated with this syndrome result in the fusion of the FGFR1 gene with various partners [1], resulting in ligandindependent FGFR activity. Patients with $\mathrm{t}(8 ; 22)$ (p11;q11) and BCR-FGFR1 fusion gene have clinical features that resemble chronic myeloid leukaemia (CML) $[2,3]$.

It has been reported that MPN with a $t(8 ; 22)$ translocation and a chimeric BCR-FGFR1 fusion gene either present or rapidly transform into an acute leukaemia $[3,4]$, usually refractory to currently available chemotherapeutic regimens including tyrosine kinase inhibitors (TKIs) $[2,5]$. No consensus on management is available for this condition. Allogeneic hematopoietic stem-cell transplantation (HSCT) is currently the only therapeutic option in BCR-FGFR1 MPN patients [6-8]. Patients who lack an HLA-matched sibling might benefit from alternative donors such as HLAhaploidentical relatives.

\section{Case Presentation}

We report the case of a 66-year-old man who was referred to us in January 2017 because of leukocytosis in a routine blood count. The patient was asymptomatic. On examination, there was no palpable lymphadenopathy, splenomegaly, or hepatomegaly.

Initial white blood cell (WBC) count was $36.7 \times 10^{9} / \mathrm{L}$, hemoglobin level $14.7 \mathrm{~g} / \mathrm{dl}$, and platelet count $600 \times 10^{9} / \mathrm{L}$. Peripheral blood (PB) examination showed leukocytosis with neutrophilia, metamyelocytes and myelocytes, basophilia, and no blasts. No eosinophilia and dysplasia were noted. LDH was $329 \mathrm{U} / \mathrm{L}$ (normal reference values 120-246 U/L). 


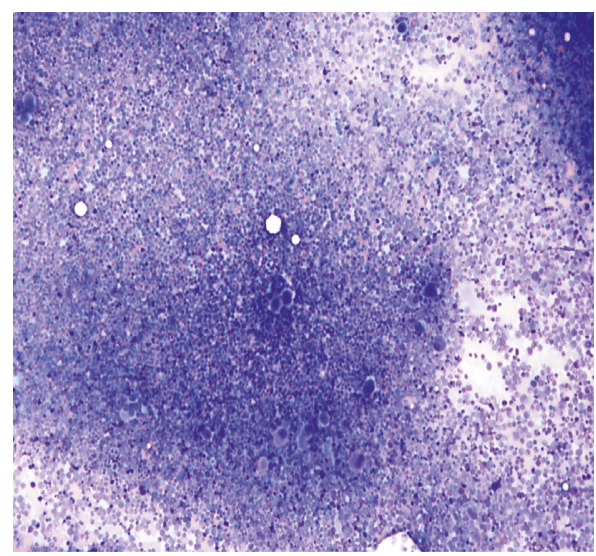

(a)
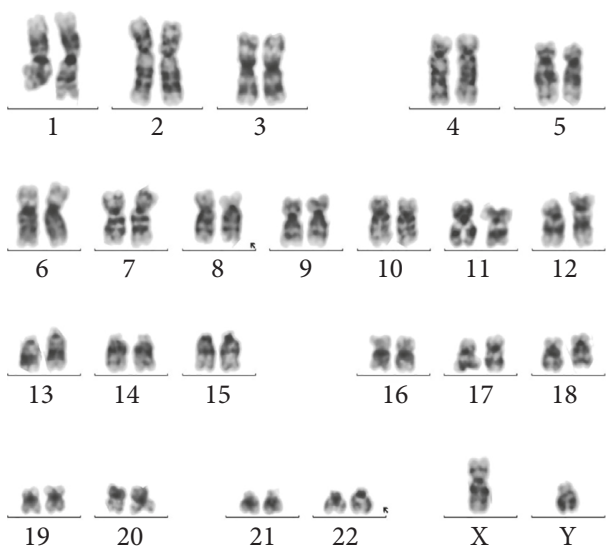

(c)

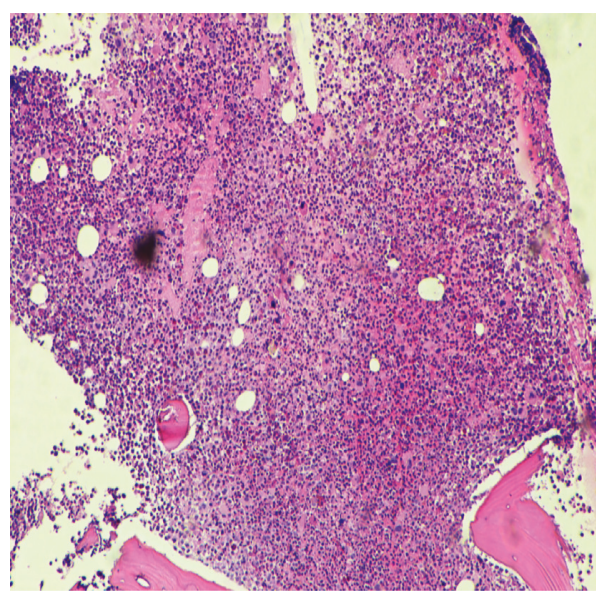

(e)

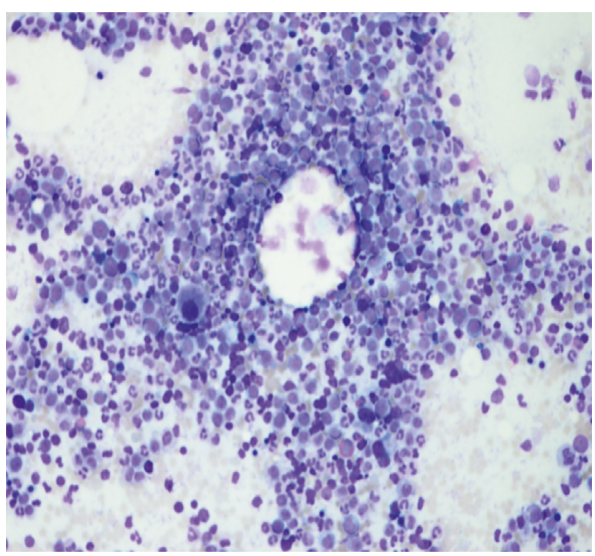

(b)

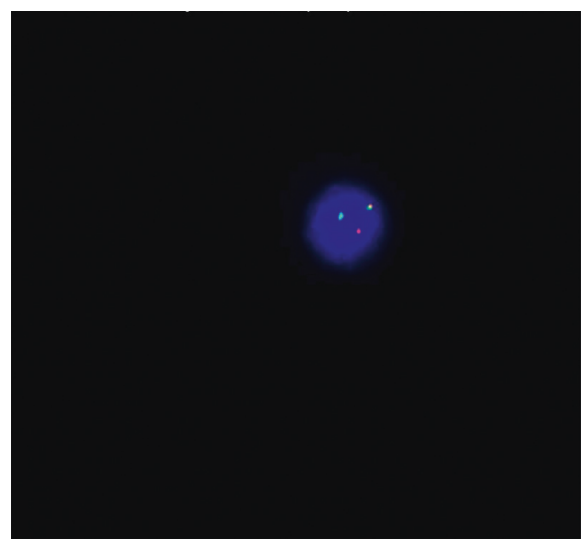

(d)

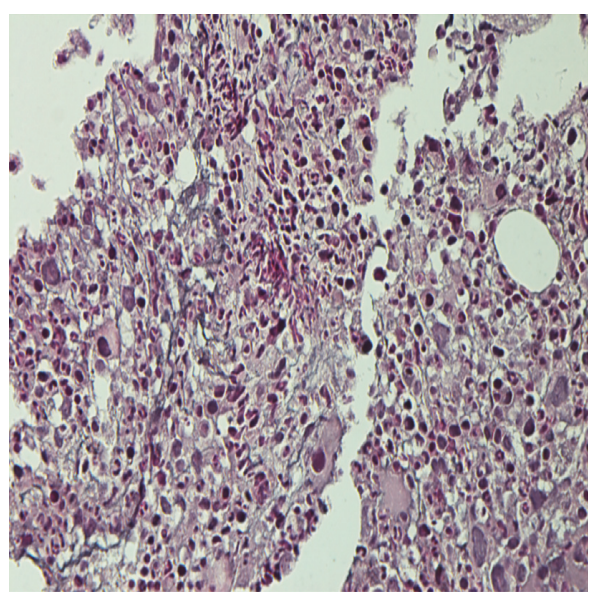

(f)

Figure 1: Bone marrow: $(a, b)$ Low magnification of the bone marrow aspirate showing myeloid hyperplasia and hypolobated megakaryocytes; (c, d) cytogenetic analysis showed a 46,XY,t(8;22)(p11;q11)[19]/46,XY[1]. Fluorescence in situ hybridization showed the split of one of the two fusion signals indicating a chromosome breakage in the FGFR1 locus; (e) low magnification of the bone marrow biopsy showing hypercellular marrow (hematoxylin and eosin); (f) reticulin stain demonstrating a mild grade of fibrosis.

A bone marrow (BM) aspirate was hypercellular with myeloid hyperplasia; myeloid/erythroid ratio was increased to $9: 1$; blast count was $0.5 \%$ per nucleated marrow cells; and mild eosinophilia was evident. BM cytogenetics showed a 46,XY,t(8;22)(p11;q11)[19]/46,XY[1]. Fluorescence in situ hybridization (FISH) with LSI FGFR1 (8p11)
Dual Color Break Apart (Abbott) showed the split of one of the two fusion signals indicating a chromosome breakage in the FGFR 1 locus in $90 \%$ of 200 cells analyzed (Figure 1).

BCR-FGFR1 reverse-transcriptase polymerase chain reaction was not possible to carry out. 
TABLE 1: Characteristics of 12 patients with BCR-FGFR1 rearrangement treated with allo-HSTCT.

\begin{tabular}{|c|c|c|c|c|c|}
\hline Case & Reference & $\begin{array}{l}\text { Age (years)/ } \\
\text { sex }\end{array}$ & Diagnosis & Donor source & Response \\
\hline 1 & Present report & $65 / \mathrm{M}$ & MPN & Haploidentical HSCT & CCyR \\
\hline 2 & Konishi et al., 2018 [8] & $48 / \mathrm{M}$ & B-ALL/MPN & Mismatched unrelated, BM & CCyR \\
\hline 3 & $\begin{array}{c}\text { Montenegro et al., } 2017 \\
{[3]}\end{array}$ & $41 / \mathrm{F}$ & B-ALL/MPN & NR & Residual disease \\
\hline 4 & Wang et al., 2016 [9] & $56 / \mathrm{F}$ & B-ALL/MPN & Matched unrelated AHSCT & $\begin{array}{c}\text { Remission for } 5 \text { months after } \\
\text { AHSCT }\end{array}$ \\
\hline 5 & $\begin{array}{l}\text { Landberg et al., } 2017 \\
{[10]}\end{array}$ & $21 / M$ & MPN & $\begin{array}{c}\text { Mismatched unrelated } \\
\text { AHSCT }\end{array}$ & $\begin{array}{c}\text { Remission for } 4 \text { years after } \\
\text { AHSCT }\end{array}$ \\
\hline 6 & $\begin{array}{c}\text { Khodadoust et al., } 2015 \\
\text { [11] }\end{array}$ & $47 / \mathrm{M}$ & $\begin{array}{l}\text { Trilineage mixed- } \\
\text { phenotype AL }\end{array}$ & $\begin{array}{c}\text { Matched sibling allogeneic } \\
\text { HSCT }\end{array}$ & Residual disease \\
\hline 7 & $\begin{array}{c}\text { Shimanuki et al., } 2013 \\
\text { [12] }\end{array}$ & $58 / \mathrm{F}$ & AL with dysplasia & $\begin{array}{c}\text { Matched sibling allogeneic } \\
\text { HSCT }\end{array}$ & $\begin{array}{c}\text { Residual disease and subsequent } \\
\text { relapse }\end{array}$ \\
\hline 8 & $\begin{array}{l}\text { Morishige et al., } 2013 \\
\text { [7] }\end{array}$ & $50 / \mathrm{M}$ & Trilineage AL/lymphoma & Cord blood & $\begin{array}{c}\text { Remission for } 2 \text { years after } \\
\text { AHSCT }\end{array}$ \\
\hline 9 & Dolan et al., 2012 [6] & $8 / \mathrm{M}$ & MDS/MPN & Unrelated AHSCT & $\begin{array}{c}\text { Remission for } 4.5 \text { years after } \\
\text { AHSCT }\end{array}$ \\
\hline 10 & Haslam et al., 2012 [13] & $21 / \mathrm{M}$ & B-ALL/MPN & $\begin{array}{c}\text { Mismatched, unrelated } \\
\text { AHSCT }\end{array}$ & Residual disease \\
\hline 11 & Kim et al., 2011 [14] & $59 / \mathrm{M}$ & Myeloid, T cell & AHSCT & CCyR \\
\hline 12 & Patnaik et al., 2010 [15] & $57 / \mathrm{F}$ & MPN & AHSCT & $\begin{array}{l}\text { Remission for } 42 \text { months after } \\
\text { AHSCT }\end{array}$ \\
\hline
\end{tabular}

Abbreviations: M: male; F: female; MPN: myeloproiferative neoplasm; B-ALL: B-cell acute lymphoblastic leukaemia; CCyR: complete cytogenetic response; AL: acute leukaemia; MDS: myelodysplastic syndrome; AHSCT: allogeneic hematopoietic stem-cell transplantation; BM: bone marrow; NR: Not reported.

The patient was initially managed with hydroxyurea. He was offered an hematopoietic stem-cell transplantation considering the poor prognosis of patients with $t(8$; 22)(p11.2;q11.2). A new BM aspirate was performed 6 weeks later due to anemia which confirmed the diagnosis. Cytogenetic analysis confirmed the presence of $t(8 ; 22)$ as the sole aberration in all 20 metaphases analyzed.

Four months later, the patient underwent an allogeneic HSCT from an HLA-haploidentical relative (haplo-HSCT). A nonmyeloablative conditioning regimen was used (cyclophosphamide, busulfan, and fludarabine). Five $\times 10^{6} / \mathrm{kg}$ CD34 cells were infused. Initial transplant course was unremarkable. Time to neutrophils $>0.5 \times 10^{9} / \mathrm{L}$ was 17 days, and time to platelets $>20 \times 10^{9} / \mathrm{L}$ was 20 days. No signs or symptoms of graft-versus-host disease (GVHD) were noted.

BM exams were performed regularly after HSCT. Cytogenetic remission as well as peripheral blood full-donor chimerism was documented from day 30 . At the time of this writing (more than 8 months from HSCT), the patient remained clinically well without evidence of GVHD and in cytogenetic complete remission.

\section{Discussion}

Hematopoietic neoplasms with FGFR1 rearrangements are uncommon entities. Most recent WHO classification [16], has included them among "myeloid and lymphoid neoplasms associated with FGFR1 abnormalities (MLNAF)," which are characterized by reciprocal chromosome translocations involving FGFR1 gene located at chromosome 8 p11 with a variety of fusion partner genes. One of the most frequently observed cytogenetic abnormalities is $\mathrm{t}(8 ; 22)$ (p11.2;q11.2). The $t(8 ; 22)$ results in an in-frame fusion of FGFR1 on 8 p11 and BCR on 22q11. The resultant fusion proteins activate tyrosine kinases which may result in the development of hematologic malignancies.

Patients with BCR-FGFR1 rearrangements may present with clinical and $\mathrm{PB}$ pictures which resemble chronic myeloid leukaemia $[2,4,15,17,18]$. The underlying BCRFGFR1 rearrangement may thus be missed, so BM cytogenetic analysis remains the mainstay of diagnosis. In our case, cytogenetic analysis confirmed the presence of $t(8 ; 22)$ as the sole aberration, and no other additional chromosomal abnormalities were observed at diagnosis or during followup.

MLNAF may rapidly progress to CML-like blast crisis. Cases of B-acute lymphoblastic leukaemia (B-ALL), T lymphoblastic lymphoma, and acute myelogeneous leukaemia (AML) have also been reported $[4,9,12-14,19,20]$.

Patients carrying the $t(8 ; 22)(\mathrm{p} 11 ; \mathrm{q} 11)$ and the subsequent BCR-FGFR1 fusion gene follow an aggressive course. There are a few reported patients who have been treated unsuccessfully with hydroxyurea [6], chemotherapy or TKIs $[2,5]$. More potent TKIs, such as ponatinib which exhibits pan-FGFR inhibitory activity, may be of clinical benefit $[10,11]$. Cardiovascular risk factors precluded the use of ponatinib in our case.

Myeloproliferative neoplasms with BCR-FGFRq rearrangement are usually refractory to chemotherapy, resulting in poor prognosis. We performed a literature search and found an additional 11 cases with BCR-FGFR1 rearrangement treated with allogeneic HSCT (Table 1), and to our knowledge, this case is the first report of a patient with a BCR-FGFR1 MPN treated with haploidentical HSCT. Haploidentical donors allow patients who lack a HLA- 
matched one to receive a HCST with outcomes which are much like those obtained with matched donors [21]. HSCT may be the only therapeutic option for long-term survival at least until more efficacious TKIs become available.

\section{Conflicts of Interest}

The authors declare that they have no conflicts of interest.

\section{Acknowledgments}

We thank Dr. Yolanda Castro for her collaboration with bone marrow sampling and pictures.

\section{References}

[1] K. Rahman, M. Kamboj, S. Qayoom, and A. Khurana, "8p11 myeloproliferative syndrome: a case report of this rare clinical entity," Indian Journal of Pathology and Microbiology, vol. 58, no. 2, pp. 254-255, 2015.

[2] A. Demiroglu, E. J. Steer, C. Heath et al., "The $t(8 ; 22)$ in chronic myeloid leukemia fuses BCR to FGFR1: transforming activity and specific inhibition of FGFR1 fusion proteins," Blood, vol. 98, no. 13, pp. 3778-3783, 2001.

[3] X. Montenegro-Garreaud, R. N. Miranda, A. Reynolds et al., "Myeloproliferative neoplasms with $\mathrm{t}(8 ; 22)(\mathrm{p} 11.2 ; \mathrm{q} 11.2) /$ BCR-FGFR1: a meta-analysis of 20 cases shows cytogenetic progression with B-lymphoid blast phase," Human Pathology, vol. 65, pp. 147-156, 2017.

[4] C. Baldazzi, I. Iacobucci, S. Luatti et al., "B-cell acute lymphoblastic leukemia as evolution of a 8 p11 myeloproliferative syndrome with $\mathrm{t}(8 ; 22)(\mathrm{p} 11 ; \mathrm{q} 11)$ and BCR-FGFR1 fusion gene," Leukemia Research, vol. 34, no. 10, pp. e282-e285, 2010.

[5] N. N. Tsyba, A. G. Turkina, E. Y. Chelysheva et al., "[A rare case of myeloproliferative disease with $\mathrm{t}(8 ; 13)(\mathrm{p} 11 ; \mathrm{q} 12)$ associated with eosinophilia and lymphadenopathy]," Terapevticheskii Arkhiv, vol. 88, no. 7, pp. 98-103, 2016.

[6] M. Dolan, A. Cioc, N. C. P. Cross, J. P. Neglia, and J. Tolar, "Favorable outcome of allogeneic hematopoietic cell transplantation for 8p11 myeloproliferative syndrome associated with BCR-FGFR1 gene fusion," Pediatric Blood \& Cancer, vol. 59, no. 1, pp. 194-196, 2012.

[7] S. Morishige, E. Oku, Y. Takata et al., "A case of 8p11 myeloproliferative syndrome with BCR-FGFR1 gene fusion presenting with trilineage acute leukemia/lymphoma, successfully treated by cord blood transplantation," Acta Haematologica, vol. 129, no. 2, pp. 83-89, 2013.

[8] Y. Konishi, T. Kondo, K. Nakao et al., "Allogeneic hematopoietic stem cell transplantation for $8 \mathrm{p} 11$ myeloproliferative syndrome with BCR-FGFR1 gene rearrangement: a case report and literature review," Bone Marrow Transplant, 2018, In press.

[9] W. Wang, G. Tang, T. Kadia et al., "Cytogenetic evolution associated with disease progression in hematopoietic neoplasms with $\mathrm{t}(8 ; 22)(\mathrm{p} 11 ; \mathrm{q} 11) / \mathrm{BCR}-\mathrm{FGFR} 1$ rearrangement," Journal of the National Comprehensive Cancer Network, vol. 14, no. 6, pp. 708-711, 2016.

[10] N. Landberg, A. Dreimane, M. Rissler, R. Billström, and H. Ågerstam, "Primary cells in BCR/FGFR1-positive 8p11 myeloproliferative syndrome are sensitive to dovitinib, ponatinib, and dasatinib," European Journal of Haematology, vol. 99, no. 5, pp. 442-448, 2017.
[11] M. S. Khodadoust, B. Luo, B. C. Medeiros et al., "Clinical activity of ponatinib in a patient with FGFR1-rearranged mixed-phenotype acute leukemia," Leukemia, vol. 30, no. 4, pp. 947-950, 2016.

[12] M. Shimanuki, T. Sonoki, H. Hosoi et al., "Acute leukemia showing $\mathrm{t}(8 ; 22)(\mathrm{p} 11 ; \mathrm{q} 11)$, myelodysplasia, CD13/CD33/ CD19 expression and immunoglobulin heavy chain gene rearrangement," Acta Haematol, vol. 129, no. 4, pp. 238-242, 2013.

[13] K. Haslam, S. E. Langabeer, J. Kelly, N. Coen, N. M. O'Connell, and E. Conneally, "Allogeneic hematopoietic stem cell transplantation for a BCR-FGFR1 myeloproliferative neoplasm presenting as acute lymphoblastic leukemia," Case Rep Hematol, vol. 2012, article 620967, 2012.

[14] S. Y. Kim, B. Oh, C. J. She et al., "8p11 Myeloproliferative syndrome with BCR-FGFR1 rearrangement presenting with T-lymphoblastic lymphoma and bone marrow stromal cell proliferation: a case report and review of the literature," Leukemia Research, vol. 35, no. 5, pp. e30-e34, 2011.

[15] M. M. Patnaik, N. Gangat, R. A. Knudson et al., "Chromosome 8p11.2 translocations: prevalence, FISH analysis for FGFR1 and MYST3, and clinicopathologic correlates in a consecutive cohort of 13 cases from a single institution," American Journal of Hematology, vol. 85, no. 4, pp. 238-242, 2010.

[16] D. A. Arber, A. Orazi, R. Hasserjian et al., "The 2016 revision to the World Health Organization classification of myeloid neoplasms and acute leukemia," Blood, vol. 127, no. 20, pp. 2391-2405, 2016.

[17] S. Richebourg, O. Theisen, I. Plantier et al., "Chronic myeloproliferative disorder with $\mathrm{t}(8 ; 22)(\mathrm{p} 11 ; \mathrm{q} 11)$ can mime clonal cytogenetic evolution of authentic chronic myelogeneous leukemia," Genes Chromosomes Cancer, vol. 47, no. 10, pp. 915-918, 2008.

[18] M. Pini, E. Gottardi, P. Scaravaglio et al., "A fourth case of BCR-FGFR1 positive CML-like disease with $\mathrm{t}(8 ; 22)$ translocation showing an extensive deletion on the derivative chromosome 8p," Hematology Journal, vol. 3, no. 6, pp. 315-316, 2002.

[19] J. J. Wakim, C. A. Tirado, W. Chen, and R. Collins, "t(8;22)/ BCR-FGFR1 myeloproliferative disorder presenting as B-acute lymphoblastic leukemia: report of a case treated with sorafenib and review of the literature," Leukemia Research, vol. 35, no. 9, pp. e151-153, 2011.

[20] A. Matikas, I. Tzannou, D. Oikonomopoulou, and M. Bakiri, "A case of acute myelogenous leukaemia characterised by the BCR-FGFR1 translocation,” BMJ Case Reports, vol. 2013, pii: bcr20130088345, 2013.

[21] D. Chen, D. Zhou, D. Guo, P. Xu, and B. Chen, "Comparison of outcomes in hematological malignancies treated with haploidentical or HLA-identical sibling hematopoietic stem cell transplantation following myeloablative conditioning: a meta-analysis," PloS One, vol. 13, no. 1, Article ID e0191955, 2018. 


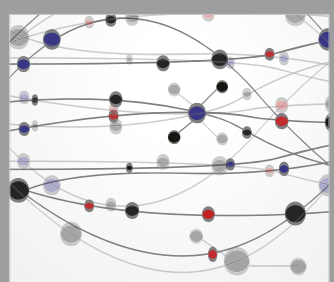

The Scientific World Journal
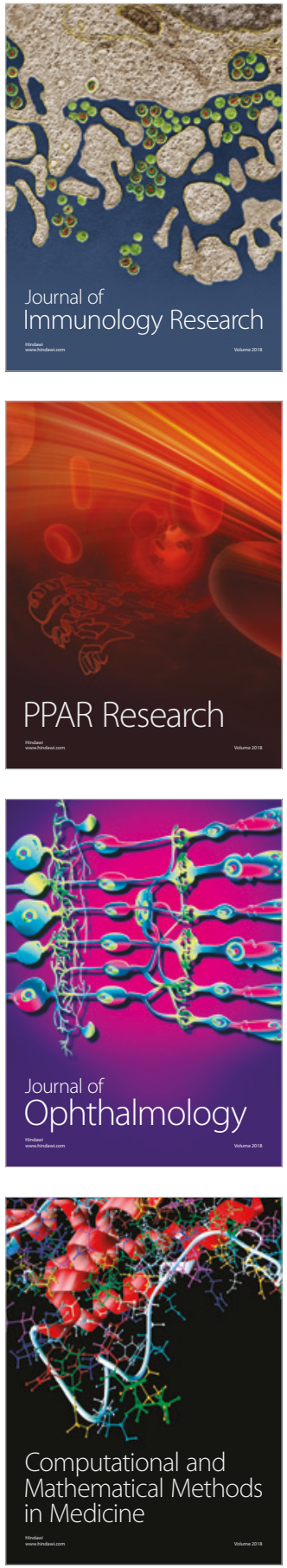

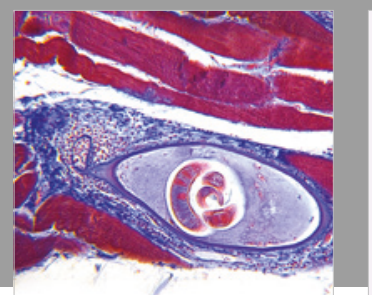

Gastroenterology Research and Practice

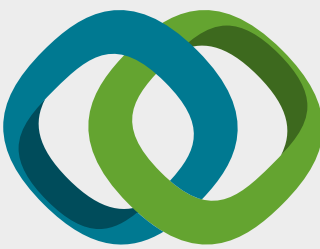

\section{Hindawi}

Submit your manuscripts at

www.hindawi.com
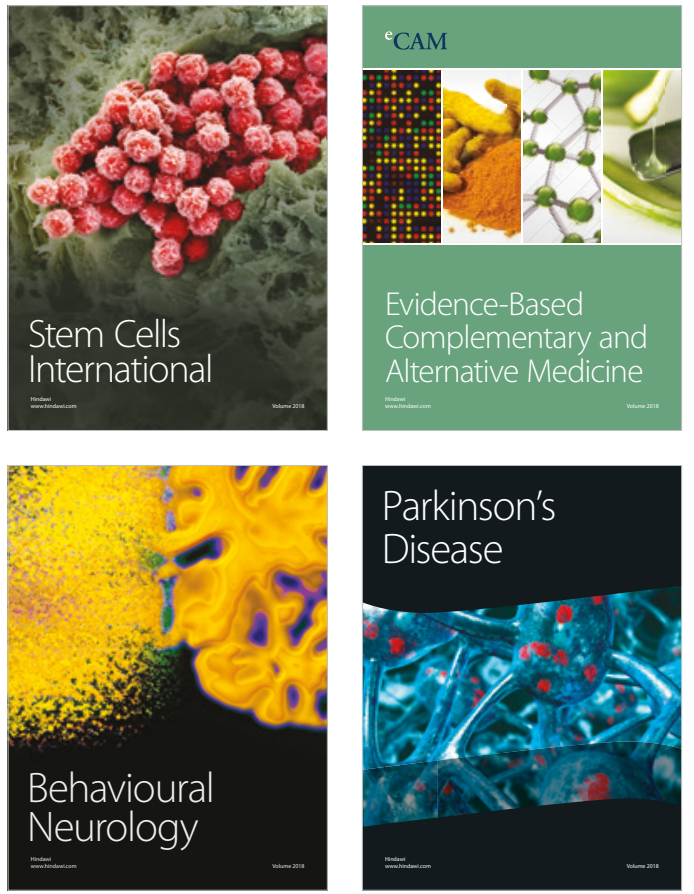

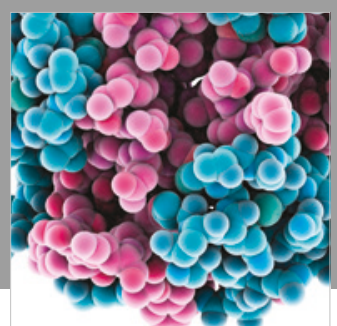

ournal of

Diabetes Research

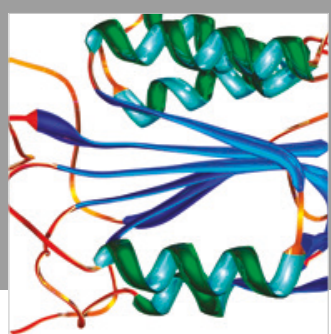

Disease Markers
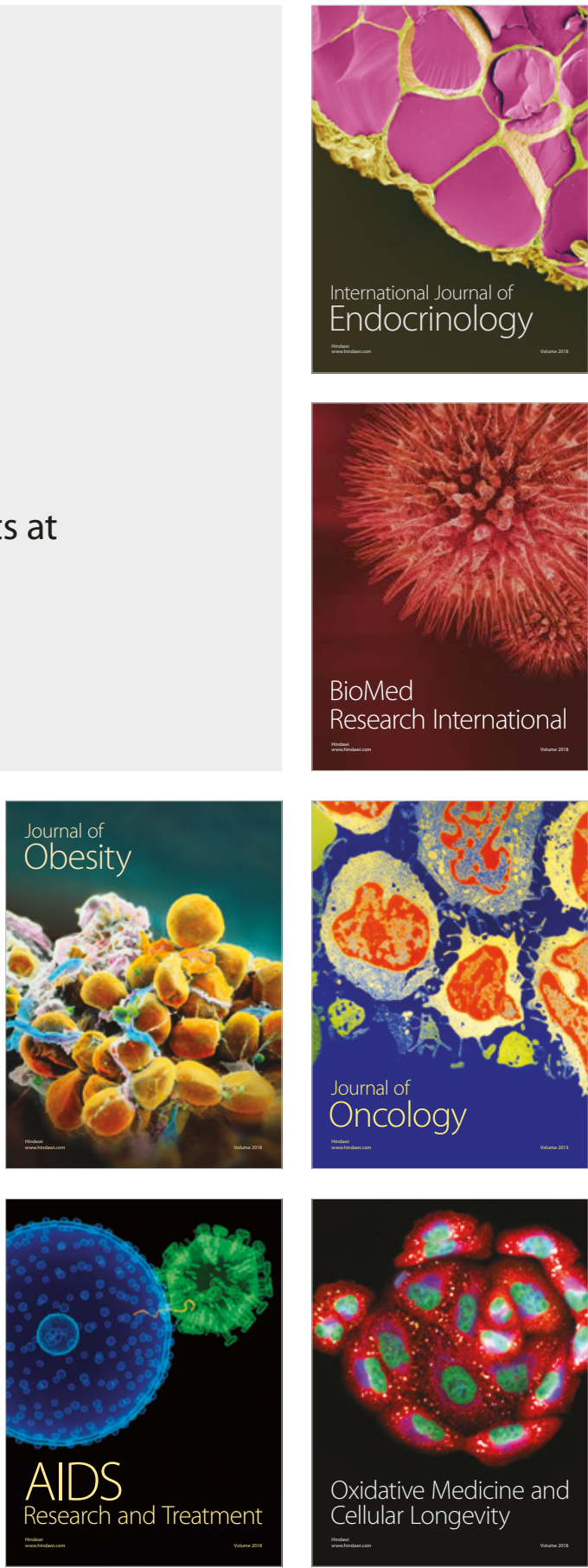